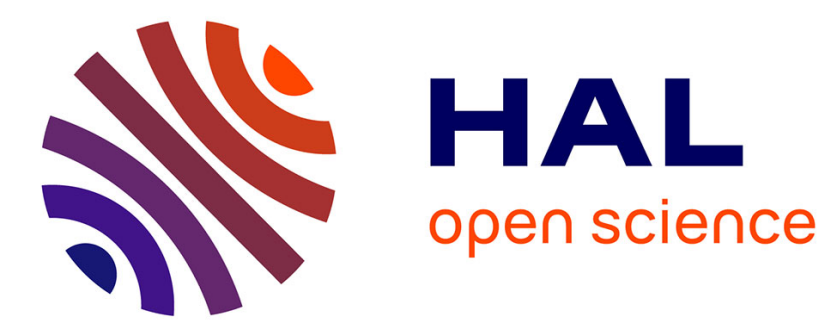

\title{
Hydatid biliocystic fistula-induced cholestasis
}

Raffaele Brustia, Fabiano Perdigao, Nikias Colignon, Olivier Scatton

\section{To cite this version:}

Raffaele Brustia, Fabiano Perdigao, Nikias Colignon, Olivier Scatton. Hydatid biliocystic fistulainduced cholestasis. Clinics and Research in Hepatology and Gastroenterology, 2015, 39 (2), pp.153154. 10.1016/j.clinre.2014.05.006 . hal-02301964

\section{HAL Id: hal-02301964 https://hal.sorbonne-universite.fr/hal-02301964}

Submitted on 30 Sep 2019

HAL is a multi-disciplinary open access archive for the deposit and dissemination of scientific research documents, whether they are published or not. The documents may come from teaching and research institutions in France or abroad, or from public or private research centers.
L'archive ouverte pluridisciplinaire HAL, est destinée au dépôt et à la diffusion de documents scientifiques de niveau recherche, publiés ou non, émanant des établissements d'enseignement et de recherche français ou étrangers, des laboratoires publics ou privés. 
Hydatid biliocystic fistula-induced cholestasis

Raffaele BRUSTIA, MD**; Fabiano PERDIGAO, MD*; Nikias COLIGNON, MD+; Olivier SCATTON, $\mathrm{MD}, \mathrm{PhD}^{* *}$;

**Department of Hepatobiliary and Liver Transplantation Surgery, Hôpital Saint Antoine, Assistance Publique-Hôpitaux de Paris, France.

+Department of Radiology, Hôpital Saint Antoine, Assistance Publique-Hôpitaux de Paris, France.

§Faculté de Médécine, Université Pierre et Marie Curie, Paris, France.

Corresponding Author:

Professor Olivier SCATTON

HPB surgery and liver transplantation Department

Hôpital Saint-Antoine

184 rue du Faubourg Saint-Antoine,

Paris 75012 Cedex

Tel: + 33 (1) 71.97.01.81

Fax: $+33(1) 71.97 .01 .57$

E-mail: olivier.scatton@sat.aphp.fr

\section{IMAGE OF THE MONTH}

Key words: obstructive jaundice; complicated hydatid cyst; biliocystic fistula; Frank Intrabiliary Rupture; Liver Surgery

Abbreviations: IV In Venous, FIR Frank Intrabiliary Rupture, ERCP Endoscopic Retrograde Cholangiopancreatography, CT Computed Tomography, MRI Magnetic Resonance Imaging, POD Post Operative Day, IPC Intermittent Pedicular Clamping

Word count: 442

The Authors declare no conflict of interest 
A 40-y-old Moroccan man without relevant past medical history was admitted for abdominal pain, fever and jaundice, without clinical signs of septic shock or peritonitis. He underwent fluid IV resuscitation and wide spectrum antibiotic regimen, with good response. No vasoactive-amine was used. Biology showed hyperleucocytosis (16 400 giga/L) and mainly conjugated (115 $\mu \mathrm{mol} / \mathrm{L})$ hyperbilirubinemia (190 $\mu \mathrm{mol} / \mathrm{L})$, with elevated liver enzymes: aspartate transaminasis (AST) $114 \mathrm{IU} / \mathrm{L}$, alanine transaminasis (ALT) $127 \mathrm{IU} / \mathrm{L}$, alkaline phosphatasis (ALP) $523 \mathrm{IU} / \mathrm{L}, \mathrm{Y}$-glutamyltransferase (GGT) $444 \mathrm{IU} / \mathrm{L}$. Hydatid serology was highly positive, and albendazole therapy was introduced. A triphasic, IV contrast-enhanced CT scan, revealed a $93 \mathrm{~mm}$ left liver hydatid cyst with no sign of intraperitoneal rupture. BiliMRI confirmed the $93 \times 86 \mathrm{~mm}$ left liver cyst with irregular low-signal-intensity rim on $\mathrm{T} 2$ weighted images, compressing the left intrahepatic bile ducts, with a cysto-biliary communication image. These findings were consistent with a Gharbi II/CE3 OMS hydatid cyst complicated by a Frank Intrabiliary Rupture (FIR) (fig. 1). An upper GI endoscopy showed some hydatid material secreted from the Vater's papilla. A sphyncterotomy was not realized. A left open hepatectomy was proposed. With hypertonic saline surgical fields protection, hepatic pedicle and left hepatic vein control was realized: left pedicular dissection, according the pure glissonian intrafascial approach (1), preceded parenchymal transection along the middle hepatic vein. After left bile duct section and removal of the specimen (fig. 2), intraoperative cholangioscopy showed patent common and right intrahepatic bile ducts with no residual hydatid material. No intermittent pedicular clamping was need, blood loss was less than $100 \mathrm{ml}$. On post operative (POD) day 5 total bilirubin was $25 \mathrm{umol} / \mathrm{L}$, prothrombine rate $80 \%$, and the postoperative course was uneventful: the patient was discharged on POD 7, and albendazole regimen continued during the following 4 weeks. 
FIR is a potentially life threatening complication that can occur in $30 \%$ of patients affected by hydatid cysts (2). Fever, right upper quadrant pain and jaundice are the most common symptoms, with evolution through cholangitis, and sepsis (3). FIR risk factors include cyst central location and diameter superior to $7.5-10 \mathrm{~cm}$. If $\mathrm{FIR}$ is greater than $5 \mathrm{~mm}$, cystic material is often seen on the bile duct (4), as it was the case in this observation. Even if diagnosis is easy in case of jaundice associated with positive serology, MRI is highly sensitive in FIR documentation.

Operative management strategies include ERCP in acute cholangitis settings as bridge to scheduled surgical treatment, or as treatment alone in older patients with severe comorbidities. Liver resection may be a radical treatment in case of FIR, being affected by lower postoperative bile leak and recurrence rate than simple unroofing or incomplete resection (3-5).

FIGURE 1

a. MRI T2-weighted sequence, showing FIR: communication among cyst and left bile duct (arrow).

b. MRI cholangiography showing left liver intrahepatic bile duct compression (small arrows), and FIR (big arrow).

FIGURE 2 Intraoperative view of left liver hydatid cyst (white arrows). 


\section{REFERENCES}

(1) Lortat-Jacob JL, Robert HG. Hepatectomie droite reglé. Press Med. 1952;60:549 -551

(2) Ramia JM, De-la-Plaza R, Quiñónes J, et al. Frank intrabiliary rupture in liver hydatidosis located in the hilar plate: a surgical challenge. Dig Surg. 2013;30:439-43

(3) Ramia JM, Figueras J, De la Plaza R, et al. Cysto-biliary communication in liver hydatidosis. Langenbecks Arch Surg. 2012;397:881-7

(4) Chautems R, Buhler LH, Gold B, et al. Surgical management and long-term outcome of complicated liver hydatid cyst caused by Echinococcus granulosus. Surgery. 2005;137:312316

(5) Prousalidis J, Kosmidis C, Anthimidis G, et al. Forty-four years experience (1963-2006) in the management of primarily infected hydatid cyst of the liver. HPB 2008;10:18-24 


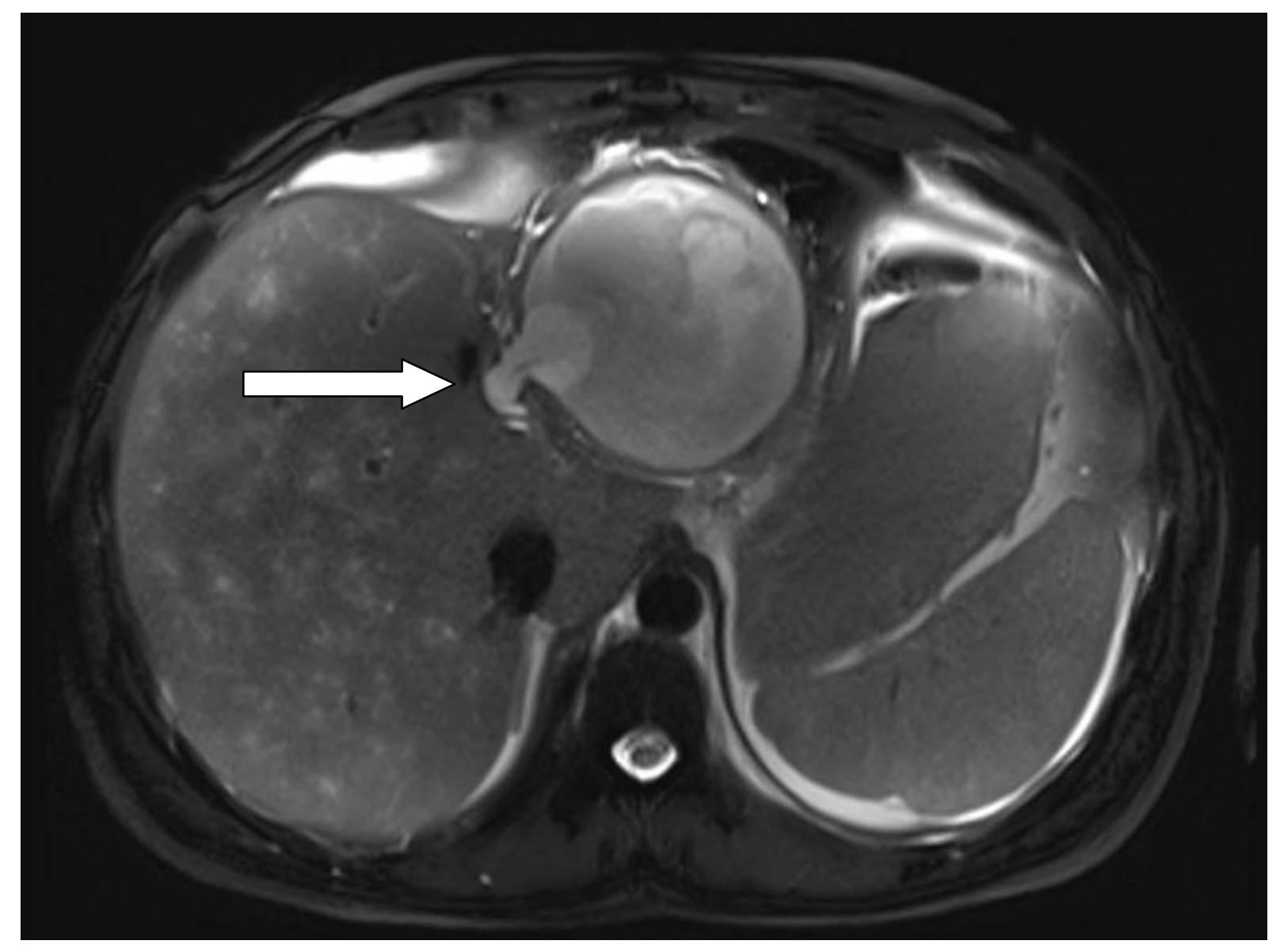

FIGURE 1.a 


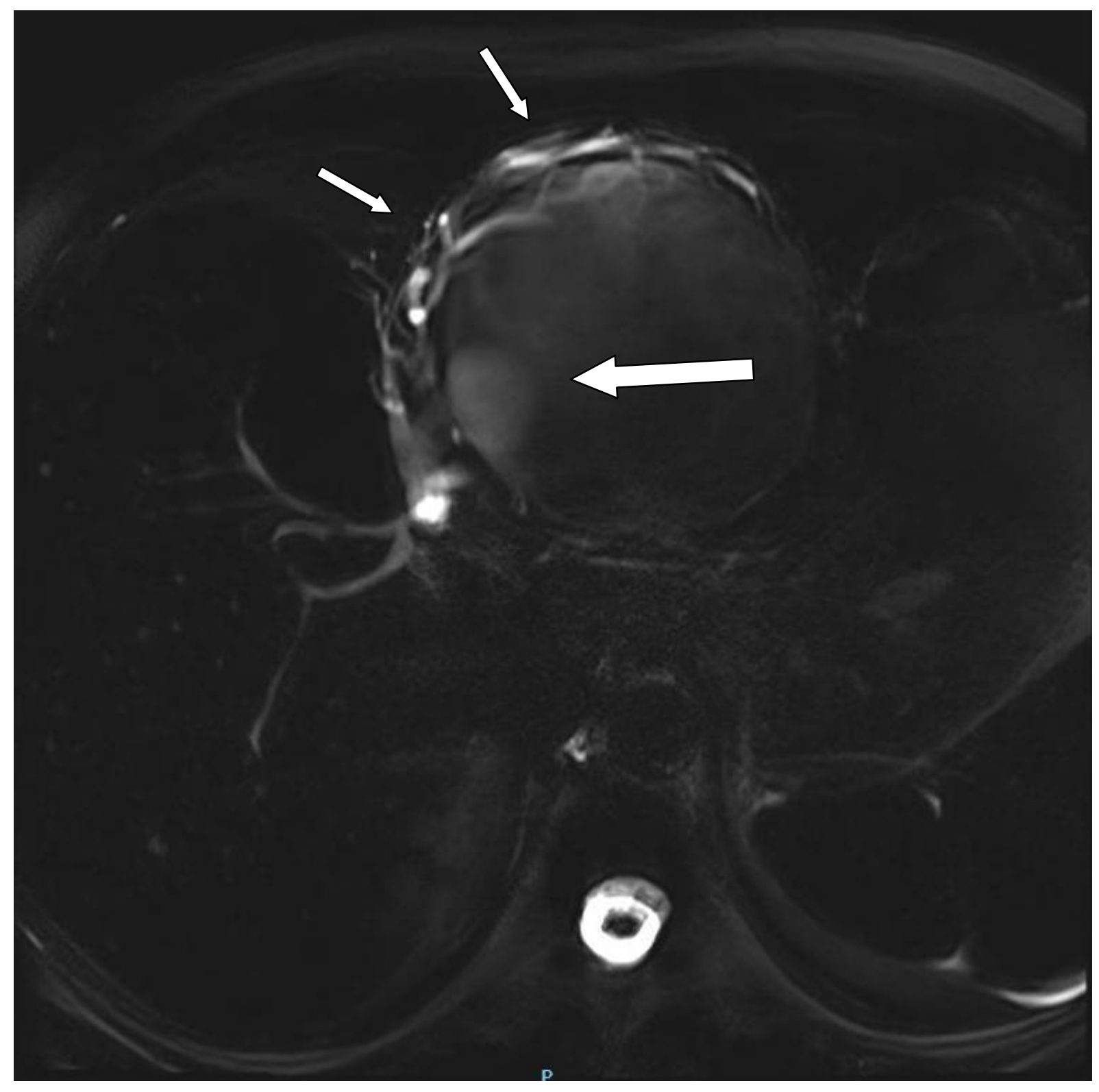

FIGURE 1.b 


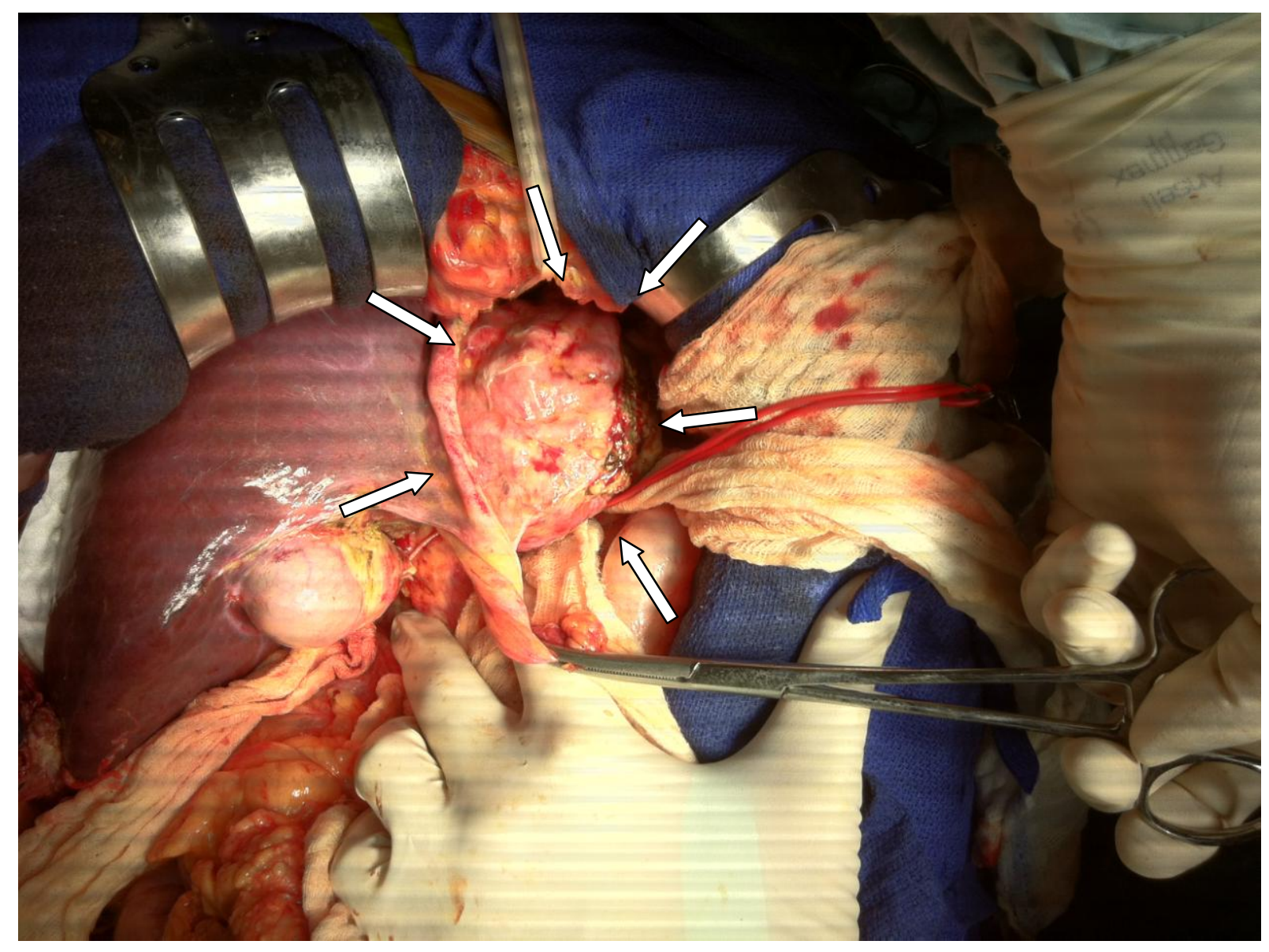

FIGURE 2 